\title{
NCD epidemic and sexual reproductive health issues in the infectious disease world
}

Editor in Chief, African Health Sciences

\author{
James K Tumwine
}

\section{DOI: https://dx.doi.org/10.4314/ahs.v19i4.1}

Cite as: Tumwine JK. NCD epidemic and sexual reproductive bealth issues in the infectious disease world. Afri Health Sci. 2019;19(4):i-iv bttps:/ / dx.doi.org/10.4314/abs.v19i4.1

The non-communicable diseases (NCDs) epidemic is now well established in sub-Sharan Africa with diabetes mellitus, cardiovascular disease, injuries and cancer coming to the fore. In this December 2019 issue of African Health Sciences, we reflect the importance of NCDs with papers on diabetes mellitus ${ }^{1-5}$, and cardiovascular disease ${ }^{6-7}$. We have also highlighted the importance of exercise ${ }^{8-9}$ in the prevention and modulation of NCDs.

This year there has been a lot of talk on climate change, the environment and health. We have an interesting paper from Egypt ${ }^{10}$, that estimates the number of hospital admission respiratory cases attributed to $\mathrm{SO}_{2}$ and $\mathrm{NO}_{2}$. Substance abuse is also a key issue affecting the health of our people. Muniu and others describe the determinants of harmful use of alcohol among adult urban slum dwellers in Kenya ${ }^{11}$, while Musamy and others describe corneal damage after the modern practice of vaping ${ }^{12}$.

The next few papers are on depression in pregnancy ${ }^{13}$, visual acuity testing in Ghana ${ }^{14}$ and use of a laryngeal mask in anaesthesia ${ }^{15}$.

Then we follow all these with sexual/reproductive health issues: sexual debut in South Africa ${ }^{16}$, sexual dysfunction among the mentally ill in Nigeria ${ }^{17}$ and high risk of human papilloma virus HPV among women with genital mutilation ${ }^{18}$. These issues continue with risk factors for dysmenorrhea among Ghanaian students ${ }^{19}$, treating menopausal flashes in Turkey $^{20}$, perception of breast cancer in Ethiopia ${ }^{21}$, attitude of women to reproductive health issues ${ }^{22}$; and awareness of congenital toxoplasmosis in Tanzania ${ }^{23}$. We conclude this theme with papers on the impact of parity and other issues of hypertensive mothers on birthweight and mode of delivery ${ }^{24}$.

Now follows perinatal mortality ${ }^{25}$ and still births ${ }^{26}$ in Nigeria. What about child nutrition? It cannot be forgotten of course. Tanzanian authors describe infant diets ${ }^{27}$, while work from Nigeria highlights the importance of child malnutrition ${ }^{28}$ and management of cerebral palsy ${ }^{29}$. It's now time for workforce and education issues. Anyim and others have an interesting treatise on stress among medical health workers ${ }^{30}$, while Mbatha and others have researched core competencies for indigenous training of traditional health workers ${ }^{31}$. Medical error. What is it exactly? Mauti and others explore this subject ${ }^{32}$, while Callaghan muses over pseudoscience in medicine ${ }^{33}$.

Then we have several papers on anaesthesia ${ }^{34-36}$. Dentistry $^{37}$ and HIV ${ }^{38-41}$ to spice this issue while the seminal paper on Peumocystis jiroveci ${ }^{42}$ is the jewel in the crown! Specific bacterial infections ${ }^{43-44}$ and schistosomiasis ${ }^{45}$ conclude this infectious disease section.

We end this editorial where we started: on non-communicable diseases; and in this case, on issues on cancer. Hence, we have papers on endometrial carcinoma ${ }^{46}$, Burkitt lymphoma $a^{47-48}$ and pleomorphic adenoma ${ }^{49}$.

Clearly as the debate on climate change and the environment enters a new gear, we need to be aware of the importance of the interplay between the environment and health, focusing on NCDs, infections and reproductive health issues.

\section{References}

1. Al-Hazmi AS. Association of Vitamin D deficiency and Vitamin D Receptor Gene Polymorphisms with Type 2 diabetes mellitus Saudi patients. Afri Health Sci. 2019;19(4):2812-2818.https://dx.doi.org/10.4314/ahs.v19i4.2 2. Anioke IC, Ezedigboh AN, Dozie-Nwakile OC, Chukwu IJ, Kalu PN. Predictors of poor glycemic control in adult with type 2 diabetes in South-Eastern Nigeria. Afri Health Sci. 2019;19(4):2819-2828. https://dx.doi.org/10.4314/ ahs.v19i4.3

3. Abiodun A, Oladimeji A, Bamidele T, Adewole A, Mayowa O. Prevalence of ECG abnormalities among adults with metabolic syndrome in a Nigerian Teaching Hospital. Afri Health Sci. 2019;19(4):2829-2838. https://dx. doi.org/10.4314/ahs.v19i4.4

4. Okukpon J, Okukpon O. Tear electrolyte assessment

(C) 2019 Tumwine JK. Licensee African Health Sciences. This is an Open Access article distributed under the terms of the Creative commons Attribution License (https://creativecommons.org/licenses/BY/4.0), which permits unrestricted use, distribution, and reproduction in any medium, provided the original work is properly cited. 
of diabetic patients in Southern Nigeria. Afri Health Sci. 2019;19(4):2839-2845.https://dx.doi.org/10.4314/ahs.v19i4.5 5. Belgacem A, Gdara NB, Khemiri I, Bitri L. Exploration of hypoglycemic effect of an extract from leaves of a plant from Tunisian pharmacopeia: artemisia campestris (asteraceae). Afri Health Sci. 2019;19(4):2846-2853. https://dx. doi.org/10.4314/ahs.v19i4.6

6. Wanghi GI, Mutombo PB, Sumaili EK. Prevalence and determinants of hypertension among students of the University of Kinshasa, Democratic Republic of Congo: a cross-sectional study. Afri Health Sci. 2019;19(4):2854-2862. https://dx.doi.org/10.4314/ahs.v19i4.7

7. Gbadegesin A, Okunola O, Ayodele O, Arogundade F, Sanusi A, Akinsola A. Renal risk profiling in newly diagnosed hypertensives in an urban population in Nigeria. Afri Health Sci. 2019;19(4):2863-2873. https://dx.doi. org/10.4314/ahs.v19i4.8

8. Abd El-Kader SM, Al-Shreef FM, Al-Jiffri OH. Impact of aerobic exercise versus resisted exercise on endothelial activation markers and inflammatory cytokines among elderly. Afri Health Sci. 2019;19(4):2874-2880. https:// dx.doi.org/10.4314/ahs.v19i4.9

9. Abd El-Kader SM, Al-Jiffri OH. mpact of aerobic versus resisted exercise training on systemic inflammation biomarkers and quality of Life among obese post-menopausal women. Afri Health Sci. 2019;19(4):2881-2891. https:/ / dx.doi.org/10.4314/ahs.v19i4.10

10. Mohammed AMF, Ibrahim YH, Saleh IA. Estimation of hospital admission respiratory disease cases attributed to exposure to $\mathrm{SO}_{2}$ and $\mathrm{NO}_{2}$ in two different sectors of Egypt. Afri Health Sci. 2019;19(4):2892-2905. https://dx.doi. org/10.4314/ahs.v19i4.11

11. Gitatui M, Kimani S, Muniu S, Okube O. Determinants of harmful use of alcohol among urban slum dwelling adults in Kenya. Afri Health Sci. 2019;19(4):29062925. https://dx.doi.org/10.4314/ahs.v19i4.12

12. Munsamy A, Bhanprakash B, Sirkhot A, Mlambo L, Dlamuka S, Mhlongo N, Naidoo R. A pre-test post-test assessment of non-invasive keratograph break up time and corneal epithelial thickness after vaping. Afri Health Sci. 2019;19(4):2926-2933. https://dx.doi.org/10.4314/ahs. v19i4.13

13. Nacar G, Taşhan ST. Relationship between sleep characteristics and depressive symptoms in last trimester of pregnancy. Afri Health Sci. 2019;19(4):2934-2944. https://dx.doi.org/10.4314/ahs.v19i4.14

14. Boadi-Kusi SB, Kwarteng MA, Asubonteng E. Development and Validation of the Minnesota Low Vision
Reading Test (MNRead) Acuity Chart for the Asante Twi Language. Afri Health Sci. 2019;19(4):2945-2953. https://dx. doi.org/10.4314/ahs.v19i4.15

15. Ombaka R, Mung'ayi V, Nekyon D, Mir S. Effect of removal of AuraOnce ${ }^{\mathrm{TM}}$ laryngeal mask in awake or deep anaesthesia: a randomized controlled trial. Afri Health Sci. 2019;19(4):2954-2963. https://dx.doi.org/10.4314/ahs. v19i4.16

16. Muchiri E, Odimegwu C. Trends and gender differences in age at sex debut among adolescents and young adults in urban Cape Area, South Africa. Afri Health Sci.2019;19(4):2964-2972.https://dx.doi.org/10.4314/ahs. v19i4.17

17. Osasona SO, Ehimigbai M. Sexual dysfunction: prevalence and associated factors in patients with mental illness receiving psychotropic medication in Nigeria. Afri Health Sci.2019;19(4):2973-2984. https://dx.doi.org/10.4314/ ahs.v19i4.18

18. Ogah J, Kolawole O, Awelimobor D. High risk human papilloma virus (HPV) common among a cohort of women with female genital mutilation. Afri Health Sci.2019;19(4):2985-2992. https://dx.doi.org/10.4314/ahs. v19i4.19

19. Osonuga A, Ekor M. Risk factors for dysmenorrhea among Ghanaian undergraduate students. Afri Health Sci.2019;19(4):2993-3000.https://dx.doi.org/10.4314/ahs. v19i4.20

20. Ozcan H, Çolak P, Oturgan B, Gülsever E. Complementary and alternative treatment methods for menopausal hot flashes used in Turkey. Afri Health Sci.2019;19(4):30013008. https://dx.doi.org/10.4314/ahs.v19i4.21

21. Agide FD, Garmaroudi G, Sadeghi R, Shakibazadeh E, Yaseri M, Koricha ZB. How do reproductive age women perceive breast cancer screening in Ethiopia? A qualitative study. Afri Health Sci.2019;19(4):3009-3017. https:// dx.doi.org/10.4314/ahs.v19i4.22

22. Idoko CA, Idoko CI,Chidolue IC. Attitude of women in a Nigerian local government to reproductive health following health education intervention. Afri Health Sci.2019;19(4):3018-3026.https://dx.doi.org/10.4314/ahs. v19i4.23

23. Onduru OG, Rumisha SF, Munyeme M, Phiri AM. Evaluation of the level of awareness of congenital toxoplasmosis and associated practices among pregnant women and health workers in Tanzania's Temeke district in Dar es Salaam. Afri Health Sci.2019;19(4):3027-3037. https:/ / dx.doi.org/10.4314/ahs.v19i4.24

24. Okoye HC, Efobi CC, Chinawa JM, Odetunde OI, Chinawa AT, Aniwada EC. Impact of parity and gesta- 
tional age of mothers with hypertension on birth weight, red blood cells and mode of delivery of their babies. Afri Health Sci.2019;19(4):3038-3044. https://dx.doi.org/10.4314/ ahs.v19i4.25

25. Ogunlesi TA, Ayeni VA, Ogunfowora OB, Jagun EO. The current pattern of facility-based perinatal and neonatal mortality in Sagamu, Nigeria. Afri Health Sci.2019;19(4):3045-3054.https://dx.doi.org/10.4314/ahs. v19i4.26

26. Anyichie NE, Nwagu EN. Prevalence and maternal socio-demographic factors associated with stillbirth in health facilities in Anambra, South-East Nigeria. Afri Health Sci.2019;19(4):3055-3062.https://dx.doi.org/10.4314/ ahs.v19i4.27

27. Kinabo J, Mamiro P, Mwanri A Bundala N, Kulwa K, Picado J, Ntwenya J, Nombo A, Mzimbiri R, Ally F, Salmini A, Juma A, Macha E, Cheung E, Msuya J. Adequacy of macro and micronutrients in infants and young children's diets in Zanzibar, Tanzania. Afri Health Sci.2019;19(4):30633077. https://dx.doi.org/10.4314/ahs.v19i4.28

28. Jude CK, Chukwunedum AU, Egbuna KO. Under-five malnutrition in a South-Eastern Nigeria metropolitan city. Afri Health Sci.2019;19(4):3078-3084. https:// dx.doi.org/10.4314/ahs.v19i4.29

29. Okenwa W, Edeh A. A review of clinical presentation and physiotherapy management of cerebral palsy patients in Esut teaching hospital, Enugu, Nigeria. Afri Health Sci.2019;19(4):3085-3090. https://dx.doi.org/10.4314/ ahs.v19i4.30

30. Anjum A, Anjum A, Anjum U, Ming X. An empirical study exploring the determinants of stress among medical healthcare professionals. Afri Health Sci.2019;19(4):30913099. https://dx.doi.org/10.4314/ahs.v19i4.31

31. Nompumelelo M, Gomo E, Gqaleni N, Ngcobo M. Core competencies acquired in indigenous training of traditional health practitioners in Kwazulu-Natal. Afri Health Sci.2019;19(4):3100-3106. https://dx.doi.org/10.4314/ ahs.v19i4.32

32. Mauti G, Githae M. Medical error reporting among physicians and nurses in Uganda. Afri Health Sci.2019;19(4):3107-3117. https://dx.doi.org/10.4314/ahs. v19i4.33

33. Callaghan C. Pseudoscience in medicine: cautionary recommendations. Afri Health Sci.2019;19(4):3118-3126. https://dx.doi.org/10.4314/ahs.v19i4.34

34. Ragazzoni L, Kwizera A, Caviglia M, Bodas M, Franc JM, Ssemmanda H, Ripoll-Gallardo A, Della-Corte F, Alenyo-Ngabirano A. Intra-operative low-dose ketamine does not reduce the cost of post-operative pain man- agement after surgery: a randomized controlled trial in a low-income country. Afri Health Sci.2019;19(4):3127-3135. https://dx.doi.org/10.4314/ahs.v19i4.35

35. Ndosi C, Mung'ayi V, Gisore E, Mir S. Effect of target controlled propofol infusion versus intermittent boluses during oesophagogastroduodenoscopy: a randomized controlled trial. Afri Health Sci.2019;19(4):3136-3145. https://dx.doi.org/10.4314/ahs.v19i4.36

36. Pengpid S, Peltzer K. Self-rated oral health status and social and health determinants among community dwelling adults in Kenya. Afri Health Sci.2019;19(4):3146-3153. https://dx.doi.org/10.4314/ahs.v19i4.37

37. Benaessa MM, Mahomed F, Ngwenya SP. A retrospective clinico-pathologic analysis of cemento-osseous dysplasia in a South African patient population. Afri Health Sci.2019;19(4):3154-3159.https://dx.doi.org/10.4314/ahs. v19i4.38

38. Adimora DE, Aye EN, Akaneme IN, Nwokenna EN, Akubuilo FE. Stigmatization and discrimination as predictors of self-esteem of people living with HIV and AIDS in Nigeria. Afri Health Sci.2019;19(4):3160-3171. https://dx.doi.org/10.4314/ahs.v19i4.39

39. Obiajulu VO, Abiola T, Izehinosen CO, Obiako RO, Aveka IA, Adam BY, Lateef TS. Psychometric validity of the distress thermometer and problem check list in ARTnaïve HIV infected patients in Northern Nigeria. Afri Health Sci.2019;19(4):3172-3180. https://dx.doi.org/10.4314/ ahs.v19i4.40

40. Biraguma J, Mutimura E, Frantz JM. Knowledge about modifiable risk factors for non-communicable diseases adults living with HIV in Rwanda. Afri Health Sci.2019;19(4):3181-3189.https://dx.doi.org/10.4314/ahs. v19i4.41

41. Cheruiyot C, Magu D, Mburugu P, Sagwe D. Uptake and utilization of institutional voluntary HIV testing and counseling services among students aged 18-24 in Kenya's public Universities. Afri Health Sci.2019;19(4):3190-3199. https://dx.doi.org/10.4314/ahs.v19i4.42

42. Govender I, Maphasha OM, Rangiah S, Steyn C. An overview of Pneumocystis jirovecii pneumonia for the African generalist practitioner. Afri Health Sci.2019;19(4):32003207. https://dx.doi.org/10.4314/ahs.v19i4.43

43. Msekandiana A, Msuya L, Philemon R, M'mbaga B, Kinabo G. Seroprevalence, risk factors and comorbidities associated with Helicobacter pylori infection amongst children receiving care at Kilimanjaro Christian Medical Center. Afri Health Sci.2019;19(4):3208-3216. https://dx.doi. org/10.4314/ahs.v19i4.44

44. Mushi MF, Alex VG, Seugendo M, Silago V, Msha- 
na SE. C - reactive protein and urinary tract infection due to Gram-negative bacteria in a pediatric population at a tertiary hospital, Mwanza, Tanzania. Afri Health Sci.2019;19(4):3217-3224. https://dx.doi.org/10.4314/ahs. v19i4.45

45. Opio CK, Rejani L, Kazibwe F, Ocama P. The diagnostic accuracy of routine clinical findings for detection of esophageal varices in rural sub-Saharan Africa where schistosomiasis is endemic. Afri Health Sci.2019;19(4):32253234.https://dx.doi.org/10.4314/ahs.v19i4.46

46. Dane C, Bakir S. The effect of myometrial invasion on prognostic factors and survival analysis in endometrial carcinoma. Afri Health Sci.2019;19(4):3235-3241. https://dx. doi.org/10.4314/ahs.v19i4.47
47. Ndede I, Mining SK, Patel K, Wanjala FM, Tenge C. Immunoglobulin heavy variable (IgHV) gene mutation and micro-RNA expression in Burkitt's lymphoma at Moi Teaching and Referral Hospital in Western Kenya. Afri Health Sci.2019;19(4):3242-3248. https://dx.doi. org/10.4314/ahs.v19i4.48

48. Ezenwosu OU, Chukwu BF, Okafor OC, Ikefuna AN, Emodi IJ. Generalized lymphadenopathy: an unusual presentation of Burkitt lymphoma in a Nigerian child: a case report. Afri Health Sci.2019;19(4):3249-3252. https://dx.doi. org/10.4314/ahs.v19i4.49

49. Khanna D, Chaubal T, Bapat R, Abdulla AM, Philip ST, Arora S. Carcinoma ex pleomorphic adenoma: a case report and review of literature. Afri Health Sci.2019;19(4):32533263. https://dx.doi.org/10.4314/ahs.v19i4.50 